\title{
Effects of medicinal waters on the UV-sensitivity of human keratinocytes - a comparative pilot study
}

\author{
Gellért Gerencsér ${ }^{1}$ • István Szabó ${ }^{1} \cdot$ Katalin Szendi $^{1}$ • Adrienn Hanzel ${ }^{1} \cdot$ Bence Raposa $^{2}$ • Zoltán Gyöngyi ${ }^{1}$ • \\ Csaba Varga ${ }^{1}$
}

Received: 13 February 2019 / Revised: 5 July 2019 / Accepted: 11 July 2019 /Published online: 1 August 2019

(C) The Author(s) 2019

\begin{abstract}
Balneotherapy has been used to treat several diseases including locomotor, neurological and dermatological conditions. The basis of the "organic hypothesis" of medical balneology is that medicinal waters, especially thermal spa and hot spring waters, contain a high variability of organic components with possible biological effects, including UV photo-protection. The recent study aims to clarify this effect in a human keratinocyte cell line model. Results confirm that organic-rich extract of selected medicinal waters might protect skin-derived cells from DNA damage. These results give a clinical relevance to medicinal waters or pharmaceutical products prepared from them in preventing the adverse effects of solar or artificial UV radiation on the human skin.
\end{abstract}

Keywords Medicinal (thermal) waters $\cdot$ Comet assay $\cdot \mathrm{UV}$ photo-protection

\section{Introduction}

Several countries apply peloids (muds) and waters of geological origin in the official medical care due to their therapeutic and preventive efficiency. A popularly applied treatment is the photo-balneotherapy in the curation of psoriasis and other skin diseases (Peroni et al. 2008). Waters used for medical purposes, however, might have adverse effects, as well, as genotoxicity studies suggest (Varga et al. 2012a). In our previous experiments several medicinal (thermal) waters rising in the area of the Pannonian Basin (central Carpathian Basin) were tested in in vitro models for genotoxicity. These studies focused on the organic fractions or concentrated extracts (isolates) of organic components prepared from the medicinal waters under study.

Volatile fractions of several waters showed a remarkable decrease in genotoxicity. For example, the Southeast (SE) Hungarian Kakasszék Spa (medicinal) water (KSZ)—also

Gellért Gerencsér

gellert.gerencser@gmail.com

1 Department of Public Health Medicine, Medical School, University of Pécs, Szigeti Street 12, Pécs 7624, Hungary

2 Research Center of Health Sciences and Laboratory Analitics, Faculty of Health Sciences, University of Pécs, Pécs, Hungary used in the recent experiment - and others reduced the baseline mutation frequency significantly, with and without metabolic activation in the Salmonella Ames test (Varga et al. 2012).

Photo-biological effects of organic extracts of 5 selected medicinal (or simply thermal) waters were also studied previously. Four out of the five investigated medicinal water isolates showed exceeding UV-protective effect on the TA 100 strains in a modified Ames test (Varga et al. 2015). Later, it became clear that the photo-protective effect was not general, i.e. not all medicinal waters were involved. KSZ medicinal water did not show any photo-protective effect using the same model, either (Gerencsér 2014). The studies mentioned above tested mainly the organic isolates prepared from the particular medicinal waters; therefore, the organic components of waters can only be suspected with modification of mutagenicity/genotoxicity and inhibition of the lethal effect of UV irradiation. Since the results were delivered by a bacterial (prokaryotic) system, they cannot absolutely be extrapolated to human tissues. Furthermore, the target cells of the UV irradiation (melano- and keratinocytes) probably have different uptake mechanisms and sensitivities (Wilson 2014; Lisby et al. 2005). Therefore, further experiments were planned with single-cell DNA strand-break studies (comet assay) on these human cells to understand the impact of the water organics on the UV effects.

Researchers have recently published in increasing number the positive effects of thermal water on the keratinocytes, and 
these studies show antioxidant, anti-inflammatory, anti-allergic, UV-protective and antiangiogenic effects (Jung et al. 2009; Varga et al. 2015; Zöller et al. 2015; Karagülle et al. 2018).

For the human skin-related study, in vitro cultures of $\mathrm{HaCaT}$ cells were chosen. $\mathrm{HaCaT}$ is a spontaneously transformed epithelial cell line derived from adult human skin, which maintains full epidermal differentiation capacity. The immortal cell line has a modified phenotype in vitro, but without malignant transformation. Cultured $\mathrm{HaCaT}$ cells have widely been used for studies in the investigative dermatology (Boukamp et al. 1988; Shing-Chuan et al. 2012).

The effect of UV irradiation on the HaCaT cells was examined in single cell gel electrophoresis (SCGE) assay, which detects DNA damage caused by genotoxic agents on eukaryotic cells in vitro or in vivo. Its alkaline version is suitable to demonstrate both single and double DNA strand breaks (Tice 1995).

The recent study aims to compare two water samples in the HaCaT cultures: a water sample which previously showed UV-protective effect in Ames test (Varga et al. 2015), Gyopáros Spa water (GYP) also located in SE Hungary, and one which did not exert any protective effect (KSZ) (Gerencsér 2014).

GYP water belongs to alkali carbonate type and is similarly rich in organic content (total organic matter, $14 \mathrm{mg} / \mathrm{L}$ ) (Fig. 1a). Balneotherapeutists recommend it in a wide range of diseases including locomotor, gynaecological, urological, neurological disorders and skin diseases.

KSZ contains a significant quantity of organic compounds (total organic matter, $65 \mathrm{mg} / \mathrm{L}$ ) (Fig. 1b). The therapeutic suggestions of this spa water involve locomotor diseases, posttraumatic states, chronic gynaecological inflammations and dermatological diseases.

\section{Materials and methods}

All samples were taken from the particular untreated spa water, and their organic extracts were prepared using a procedure involving isolation of organics on Amberlite XAD macroreticular adsorbent resins as described elsewhere (Varga 1988, 1991; Varga et al. 1998; Hanzel et al. 2019). The ethanolic eluates $(80 \%)$ represented 1000 -fold concentration of the original organic contents of the particular water samples.

\section{Cell culture}

HaCaT cells were cultured on $75 \mathrm{~cm}^{2}$ cell culture dishes, in RPMI 1640 Medium (Sigma-Aldrich, St. Louis, USA) supplemented with $10 \%$ fetal bovine serum and $10 \mathrm{~mL} / \mathrm{L}$ PenStrep (all from Sigma-Aldrich). Cultures were incubated at $37{ }^{\circ} \mathrm{C}$ with $5 \% \mathrm{CO}_{2}$ concentration. Trypsin-EDTA solution (1×) (Sigma-Aldrich) was used to harvest cells.

\section{Comet assay on human keratinocytes}

Three layer gels were applied on fully frosted microscopic slides. An NMA (normal melting point agarose, $0.5 \%$ ) was followed by a middle and a covering layer of LMPA (low melting point agarose, $0.5 \%$ ). The NMA solution was mixed with the water concentrates (1:1) prior to preparing the first layer, whereas the keratinocyte cells were suspended in the middle layer.

The slides were irradiated with a Philips TUV $30 \mathrm{~W}$ Germicidal G30 T8 lamp (emission maximum at $254 \mathrm{~nm}$ for UV-C, the dose of UV-A was $0.03 \mathrm{~mW} / \mathrm{cm}^{2}$ and by UV-B was $0.79 \mathrm{MED} / \mathrm{HR}$ ) at a distance of $15 \mathrm{~cm}$. Incubation was performed in a wet chamber $\left(37^{\circ} \mathrm{C}\right.$, dark).

The cells were then lysed with high concentration solution (1\% sodium sarcosinate, $2.5 \mathrm{M} \mathrm{NaCl}, 100 \mathrm{mM} \mathrm{Na}$-EDTA, $1 \%$ Triton $\mathrm{X}-100,10 \%$ DMSO and $10 \mathrm{mM}$ Tris) for $1 \mathrm{~h}$ at $4{ }^{\circ} \mathrm{C}$, and the nuclear DNA was electrophoresed under alkaline condition which partially disrupts secondary structure and allows the movement of DNA fragments in the agarose. Prior to electrophoresis, the slides were immersed for $20 \mathrm{~min}$ in the electrophoresis buffer (200 mM EDTA, $10 \mathrm{~N} \mathrm{NaOH}, \mathrm{pH} 10)$. The electrophoresis was performed for $40 \mathrm{~min}$ at $0.46 \mathrm{~V} / \mathrm{cm}$ and $132 \mathrm{~mA}$ in total darkness. Then the slides were neutralised for 3 times 5 min with buffer $(0.4 \mathrm{M}$ Tris) and stained with ethidium bromide ( $50 \mu \mathrm{l}-2 \mu \mathrm{g} / \mathrm{mL})$. Fluorescence microscopy was used to visualise the images (comets) representing the DNA damage (Singh et al. 1988). Fifty nuclei were analysed on each slide using Comet Assay IV software (Perceptive Instruments Ltd., 400X). The degree of DNA damage is termed as tail moment (TM) and is calculated by multiplying the tail length by the percentage of DNA in the tail.

\section{Statistical analysis}

For the evaluation of the results, the Mann-Whitney $U$ test of the SPSS Statistics 21 program was used. The $p$ value (with the significance level $<0.05$ ) was defined compared with the parallel controls in all series (Fourie et al. 2007).

\section{Experimental protocol}

Treatment \#1 involved UV irradiation alone. Duration of UV exposure was 10, 20, 30, 40 and $50 \mathrm{~s}$ respectively. Slides without UV exposure served as negative controls. Cells were treated with KSZ water in treatment \#2 together with UV exposures of 10, 20, 30, 40 and $50 \mathrm{~s}$, respectively. In treatment $\# 3$, cells were treated as in \#2 but it was combined with 1-h incubation. During treatment \#4/5, cells were treated with KSZ and GYP, respectively. According to our previous measurements, the optimal, 30-s UV exposure was applied together with the incubation periods of $0.5,1,1.5,2$ and $2.5 \mathrm{~h}$, respectively. In treatment \#6, UV irradiation was combined with post-incubation to exclude the single role of incubation 

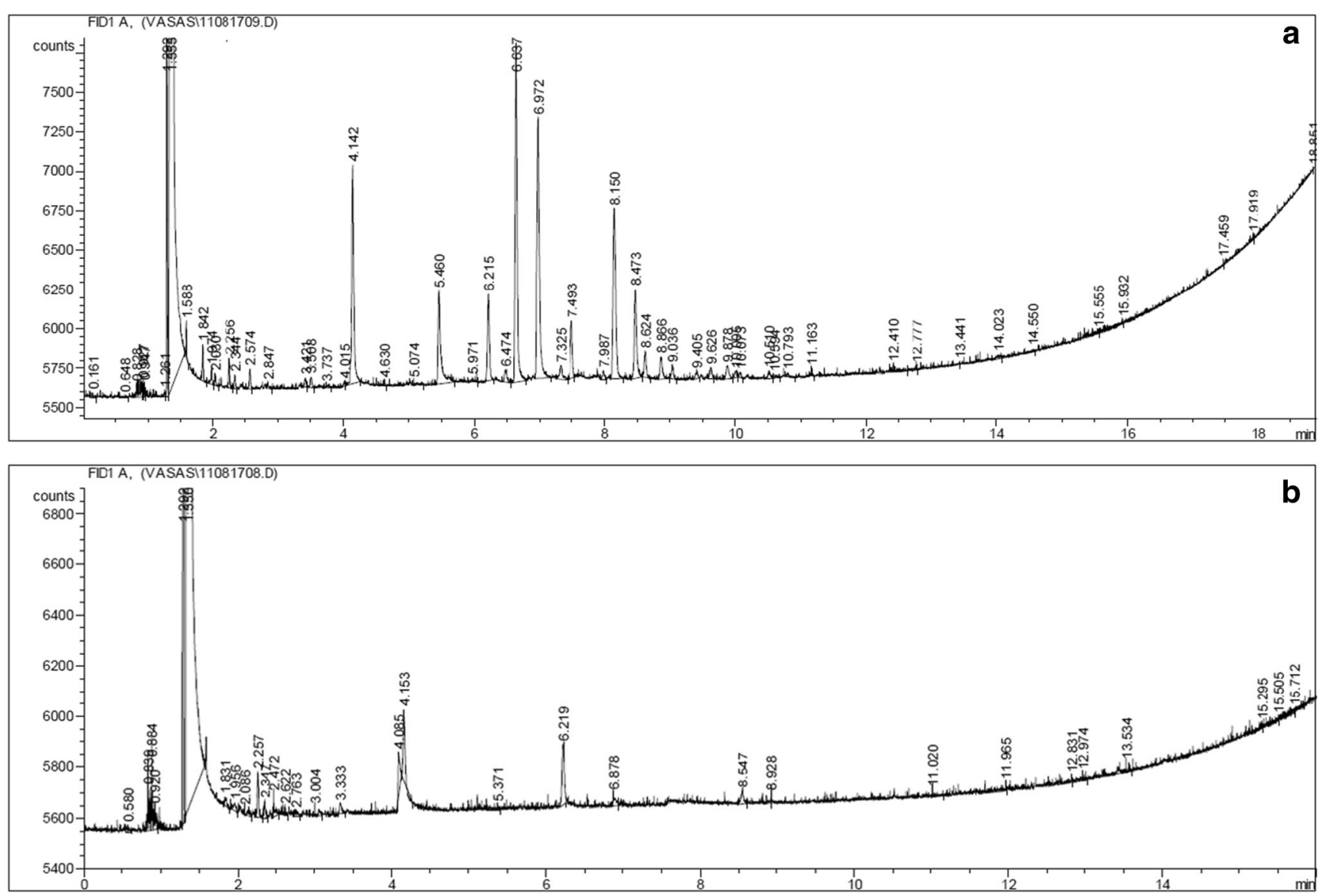

Fig. 1 Gas chromatograms of Gyopáros Spa (a) and Kakasszék Spa (b)

and repair enzymes and to confirm the possible UV-protective effect of GYP medicinal water. A 30-s UV exposure was followed by an incubation of $0.5,1,1.5,2$ and $2.5 \mathrm{~h}$, respectively. Slides without exposure and incubation served as negative controls. Irradiated slides without incubation served as positive controls (Table 1).

\section{Results}

In our subsequent investigations, genotoxic effects of medicinal water concentrates were also tested, besides the possible role of the extracts in protection from UV radiation. In the case of GYP water, genotoxic effects can clearly be excluded. In contrast, genotoxicity cannot be either ruled out or confirmed in the case of $\mathrm{KSZ}$ sample as the investigations produced results for both.

In the calibration study (treatment \#1), even the shortest period of UV exposure caused a significant difference in the tail moments. A linear relationship can be found between the duration of the exposure and the DNA fragmentation, as expected (Remenyik et al. 1999) (Fig. 2a).

Table 1 Experimental protocol

\begin{tabular}{llll}
\hline Treatment & Water treatment & UV-irradiation time (s) & Incubation period (h) \\
\hline$\# 1$ & - & $10,20,30,40,50$ & - \\
$\# 2$ & KSZ & $10,20,30,40,50$ & - \\
$\# 3$ & KSZ & $10,20,30,40,50$ & 1 \\
$\# 4 / 5$ & KSZ/GYP & 30 & $0.5,1,1.5,2,2.5$ \\
$\# 6$ & - & 30 & $0.5,1,1.5,2,2.5$ \\
\hline
\end{tabular}



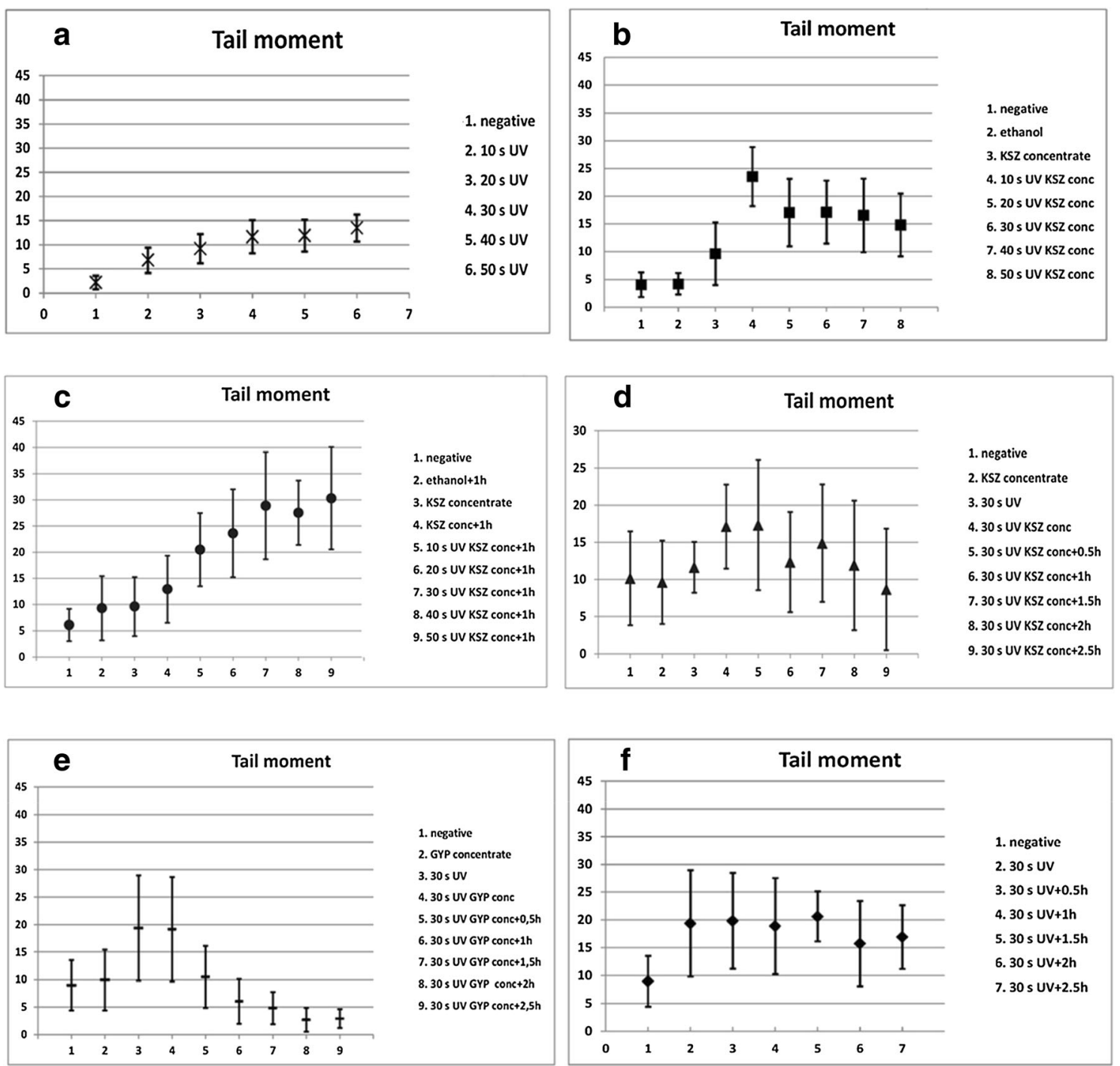

Fig. 2 Results of the comet assay. a Effect of UV irradiation alone (treatment \#1). b Effect of KSZ sample on the UV effects, without incubation (treatment \#2). $\mathbf{c}$ Effects of 1-h incubation with KSZ on the UV-sensitivity (treatment \#3). d Effects of the incubation time on UV

Treatment \#2: As summed up in Fig. 2b, no protective effect of KSZ isolate against UV was detected. Comparing to the ethanol (vehicle) control, the 10-, 20-, 30-, 40- and 50 -s UV irradiation also caused significantly higher degradation $(p<0.001)$.

Treatment \#3: When the cells were treated with KSZ isolate and incubated for $1 \mathrm{~h}$ after 10-50-s UV irradiation, all the samples have significantly $(p<0.001)$ higher TMs than all the negative controls (negative, ethanol $+1 \mathrm{~h}, \mathrm{KSZ}$ conc, $\mathrm{KSZ}$ conc $+1 \mathrm{~h}$ ); therefore, there was no promoting effect of 1-h incubation (Fig. 2c).

Treatment \#4: In the case of KSZ water, the protective effect could only be shown when cells were incubated for at least $2-2.5 \mathrm{~h}$ following 30 -s irradiation $(p<0.001)$ (Fig. 2d).

sensitivity in cells treated with the KSZ sample (treatment \#4). e Effects of the incubation time on UV sensitivity in cells treated with the GYP sample (treatment \#5). $\mathbf{f}$ Effect of post-incubation time on DNA degradation after UV exposures (treatment \#6)

Treatment \#5: GYP water-treated cells showed the same or lower levels of fragmentation compared with the negative control (30-s UV GYP conc), even following 0.5-h incubation. The longer incubation periods (1-1.5-2-2.5 h) revealed a remarkable further decrease in fragmentation results $(p<0.001)$ (Fig. 2e).

Treatment \#6: As the last step, we investigated if the medicinal water concentrate and the length of the incubation time together play a role in the development of protective effect. It could clearly be confirmed that incubation time itself is not sufficient for the DNA-repair mechanism (Fig. 2f).

Figure 3 contains some typical pictures about the different types of treatments that were analysed using the software Comet Assay IV. 
Fig. 3 Some pictures about comet assays (Comet Assay IV

software, Perceptive Instruments Ltd., 400X). a Negative control. b Ethanol control. c 30-s UV exposure. d KSZ isolate and 30-s UV irradiation, without incubation. e KSZ sample and incubated for $1 \mathrm{~h}$ after 30-s UV exposure. f GYP isolate and 30-s UV irradiation, without incubation. g GYp sample and incubated for $1 \mathrm{~h}$ after 30 s UV exposure. $\mathbf{h}$ Effect of 1-h post-incubation time after 30 -s UV exposures

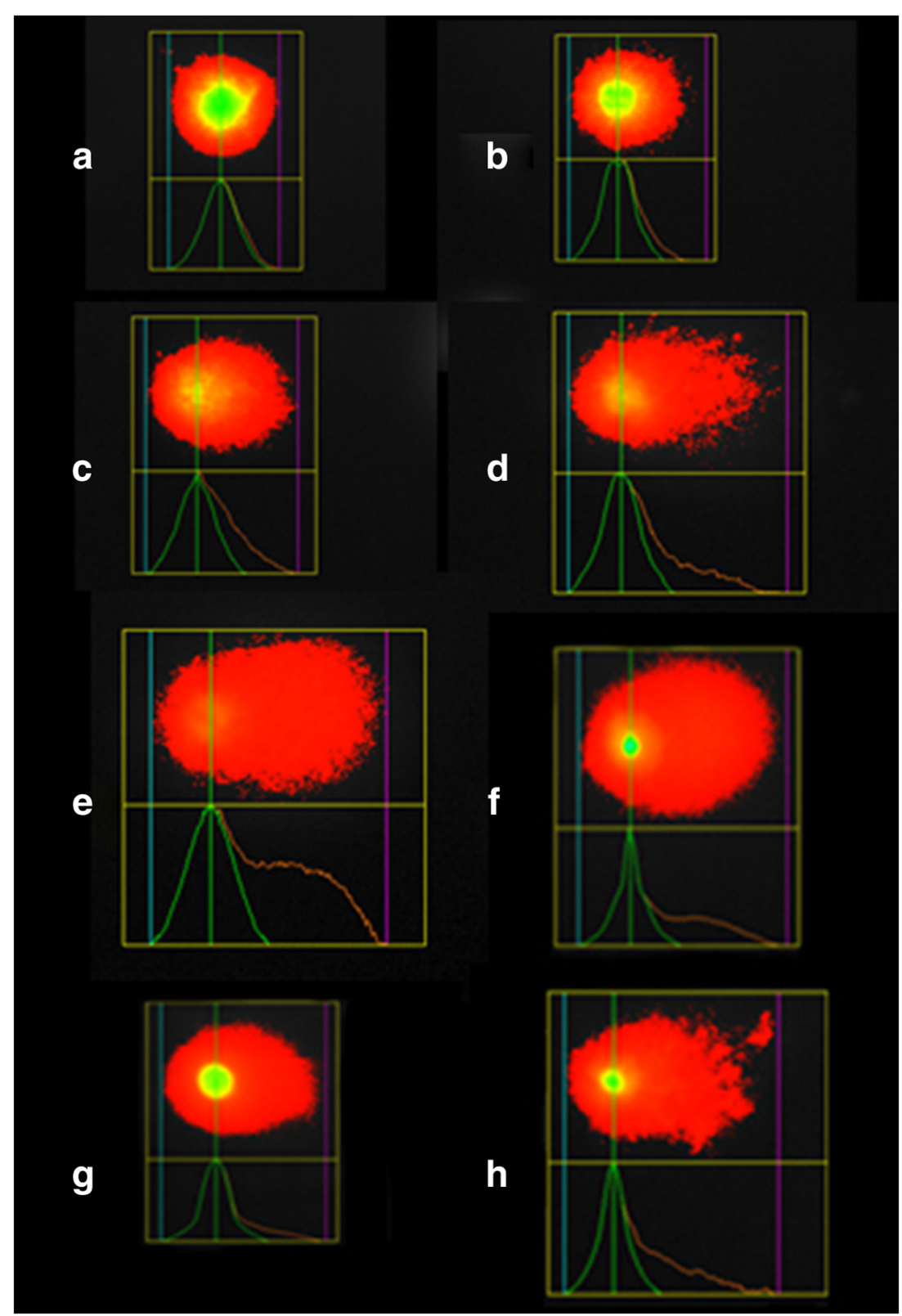

\section{Discussion}

This study was initiated from Varga's "organic hypothesis" (Varga 2010a, b; Hanzel et al. 2019) of biological activity and therapeutic efficiency of medicinal waters of geological origin in different skin, gynaecological and rheumatic disorders (Varga and Malmer 2010; Kulisch et al. 2014). These-mainly thermal-waters contain relatively high amount of inorganic salts (cations/anions) and dissolved gases but only few of them have proved to be therapeutically effective during dermal exposure, i.e. bathing (e.g. sulphuric compounds, $\mathrm{CO}_{2}$, radon) (Kulisch et al. 2014; Kovács et al. 2012). Medicinal waters, however, also contain several organics in a great variety and abundance. Some of them may have either advantageous or toxic effects even in a very low concentration, as previously indicated (Varga 2012a, b). The idea of possible protecting or sensitising UVrelated effects of thermal waters is based upon the wellknown effectiveness of balneo-phototherapy in psoriasis treatment (Abels and Kattan 1985). Our studies were performed on human keratinocytes, because results delivered earlier by a bacterial (prokaryotic) system can be extrapolated neither to humans nor human skin-derived cells. The uptake of and sensitivity to the organics may be completely different in human cells, and their metabolism cannot exactly be modelled by the standard rat liver enzyme preparation. 
The two organic-rich medicinal water under study showed relevant biological effects in the previous studies performed by in vitro bacterial tests. In an in toto study, volatile compounds of KSZ water decreased the negative control revertant rate of Salmonella TA 100 bacteria with $50 \%$ in the desiccators' Ames test, modified especially for the volatile mutagens (Varga et al. 2015). This phenomenon could not be unequivocally explained. In the UV-survival test on the Salmonella Ames tester strains (Gerencsér 2014), an organic isolate of this water did not show any effect, meanwhile, GYP sample prepared the same way, did (Gerencsér 2014). Upon fatal UVB/C irradiation, this latter caused 14 and $21 \%$ survival of TA 100 bacteria, without and with metabolic activation, respectively. This protective effect seemed incubation dependent: combined with the UV exposure, the bacteria should have been treated with the water isolates at $37^{\circ} \mathrm{C}$, for $8 \mathrm{~h}$.

The behaviour of the two diverse water samples seemed also completely different in human keratinocyte cultures. The single cell DNA electrophoresis assay suggested that only the GYP isolate prevented the cells from the consequence of UV exposure. The protective effect could already be detected after a 0.5 -h postincubation (repair) period. In the absence of water isolates, the UV-induced DNA lesions were not repaired otherwise within a 2.5 -h period, either. This finding confirms results suggested by the bacterial studies on the UV-protective effects: GYP water isolate is efficient in human keratinocytes, as well.

What kinds of compounds played a role in these particular processes? They must be organic compounds since the preparations contained only organics. However, they could not be simple phenolic (methyl-, dimethyl-, ethyl-) substances, because these latter have already been identified in the ineffective KSZ water isolate in a great amount by mass spectrometry (Varga 2012b).

UV irradiation initiates the formation of free radicals in the skin, having an adverse impact on epidermal cells and leading to chronic skin lesions, ageing and photo-carcinogenesis (Emri 2004). Medicinal waters or pharmaceutical products prepared from them may have a great role in preventing the adverse effects of solar or artificial UV radiation on human skin.

Acknowledgements The present scientific contribution is dedicated to the 650th anniversary of the foundation of the Univerity of Pécs, Hungary.

Funding information Open access funding provided by University of PÃ@cs (PTE). This work was financially supported by the Faculty of Medicine, University of Pécs (PTE-AOK-KA-2013/34039).

\section{Compliance with ethical standards}

Conflict of interest The authors declare that they have no conflicts of interest.
Open Access This article is distributed under the terms of the Creative Commons Attribution 4.0 International License (http:// creativecommons.org/licenses/by/4.0/), which permits unrestricted use, distribution, and reproduction in any medium, provided you give appropriate credit to the original author(s) and the source, provide a link to the Creative Commons license, and indicate if changes were made.

\section{References}

Abels DJ, Kattan BJ (1985) Psoriasis treatment at the Dead Sea: a natural selective ultraviolet phototherapy. J Am Acad Dermatol 12:639-643

Boukamp P, Petrussevska RT, Breitkreutz D, Hornung J, Markham A, Fusenig NE (1988) Normal keratinization in a spontaneously immortalized aneuploid human keratinocyte cell line. JCB 106:761-771

Emri G (2004) UV-irradiation induced DNA-damage and repair in skin cells. In vitro methods. $\mathrm{PhD}$ thesis, University of Debrecen, Hungary, pp 1-68 https://dea.lib.unideb.hu/dea/bitstream/handle/ 2437/2655/Emri_Gabriella_tezis_angol.pdf;jsessionid= 0C8EDCA21 C02DDB3945E 3 A 5CBC092A68? sequence $=2$. Accessed 2018

Fourie F, Reinecke SA, Reineckek AJ (2007) The determination of earthworm species sensitivity differences to cadmium genotoxicity using the comet assay. Ecotoxicol Environ Saf 67:361-368. https://doi. org/10.1016/j.ecoenv.2006.10.005

Gerencsér G (2014) Experimental balneology: the biological effects of medicinal water and mud samples from the Carpathian Basin. Phd thesis, University of Pécs, Hungary, pp 1-18 http://doktoriiskola. etk.pte.hu/dok/doktoriiskola/disszertaciok/Gelencser_eng.pdf. Accessed 2018

Hanzel A, Berényi K, Horváth K, Szendi K, Németh B, Varga C (2019) Evidence for the therapeutic effect of the organic content in Szigetvár thermal water on osteoarthritis: a double-blind, randomized, controlled clinical trial. Int J Biometeorol 63:449-458. https:// doi.org/10.1007/s00484-019-01676-3

Jung SH, Seo YK, Youn MY, Park CS, Song KY, Park JK (2009) Antiaging and anti-inflammation effects of natural mineral extract on skin keratinocytes. Biotechnol Bioprocess Eng 14:861-868

Karagülle MZ, Karagülle M, Kılıç S, Sevinç H, Dündar C, Türkoğlu M (2018) In vitro evaluation of natural thermal mineral waters in human keratinocyte cells: a preliminary study. Int J Biometeorol 62: 1657-1661. https://doi.org/10.1007/s00484-018-1565-8

Kovács C, Pecze M, Tihanyi A, Kovács L, Balogh S, Bender T (2012) The effect of sulphurous water in patients with osteoarthritis of hand. Double-blind, randomized, controlled follow-up study. Clin Rheumatol 31:1437-1442. https://doi.org/10.1007/s10067-0122026-0

Kulisch A, Benko A, Bergmann A, Gyarmati N, Horváth H, Kránicz Á, Mándó ZS, Matán Á, Németh A, Szakál E, Szántó D, Szekeres L, Bender T (2014) Evaluation of the effect of Lake Heviz thermal mineral water in patients with osteoarthritis of the knee: a randomized, controlled, single-blind, follow-up study. Eur J Phys Rehabil Med 50:373-381

Lisby S, Gniadecki R, Wulf HC (2005) UV-induced DNA damage in human keratinocytes: quantitation and correlation with long-term survival. Exp Dermatol 14:349-355. https://doi.org/10.1111/j. 0906-6705.2005.00282.x

Peroni A, Gisondi P, Zanoni M, Girolomoni G (2008) Balneotherapy for chronic plaque psoriasis at Comano spa in Trentino, Italy. Dermatol Ther 21:31-38. https://doi.org/10.1111/j.1529-8019.2008.00200.x

Remenyik É, Varga C, Emri G, Hunyadi J, Horkai I (1999) Comet assay to study UV-induced DNA damage. In: Holick MF, Jung EG (eds) Biologic effects of light. Boston, Dordrecht, London, pp 41-43 
Shing-Chuan S, Woan-Rouh L, Liang-Yo Y, Tsai HH, Yang LL, Chen YC (2012) Quercetin enhancement of arsenic-induced apoptosis via stimulating ROS-dependent $\mathrm{p} 53$ protein ubiquitination in human HaCaT keratinocytes. Exp Dermatol 21:370-375. https://doi.org/ 10.1111/j.1600-0625.2012.01479.x

Singh NP, McCoy MT, Tice RR, Schneider EL (1988) A simple technique for quantification of low levels of DNA damage in individual cells. Exp Cell Res 175:184-191

Tice RR (1995) The single cell gel/comet assay: a microgel electrophoretic technique for the detection of DNA damage and repair in individual cells. In: Phillips DH, Venitt S (eds) Environmental Mutagenesis. Oxford, pp 315-339

Varga C (1988) Chlorinated drinking water XAD isolates do not affect the sister chromatid exchange frequency. Int Arch Occup Environ Health 61:147-149

Varga C (1991) Genotoxicologic evalution of ozonated/chlorinated drinking water: cytogenetic effects of XAD-fractions on cultured human cells. Environ Toxicol Chem 10:1029-1035. https://doi.org/10. 1007/BF00381619

Varga C (2010a) Balneoprevention: new approaches. Int J Biometeorol 56:195-197. https://doi.org/10.1007/s00484-010-0377-2

Varga C (2010b) Problems with classification of spa waters used in balneology. Health 2:1260-1263. https://doi.org/10.4236/health.2010. 211187
Varga C (2012a) Volatile organics in thermal spa waters: active ingredients or environmental toxicants? Therm Spa Med 2:1-8

Varga C (2012b) Water hygiene and toxicology: actual problems and new research trends in Hungary. Acta Biol Debr Oecol Hung 29:9-120

Varga P, Malmer N (2010) Gynaecological rehabilitation: recent experiences with sulphuric thermal spa water in Harkany. La Presse Thermale Et Climatique 147:19

Varga C, Groska L, Kocsár B et al (1998) Patent: extract comprising organic components of natural water, process for producing them and cosmetics comprising this extract

Varga C, László M, Gerencsér G, Gyöngyi Z, Szendi K (2015) Natural UVprotective organic matter in thermal water. J Photochem Photobiol B 44:8-10. https://doi.org/10.1016/j.jphotobiol.2015.01.007

Wilson VG (2014) Growth and differentiation of HaCaT keratinocytes. Methods Mol Biol 1195:33-41. https://doi.org/10.1007/7651_ 2013 42

Zöller N, Valesky E, Hofmann M, Bereiter-Hahn J, Bernd A, Kaufmann R, Meissner M, Kippenberger S (2015) Impact of different spa water on inflammation parameters in human keratinocyte $\mathrm{HaCaT}$ cells. Ann Dermatol 27:709-714. https://doi.org/10.5021/ad.2015.27.6.709 